\title{
Effectiveness of Budgeting and Budgetary Control on the Performance of Ado-Ekiti Local Government in Nigeria
}

\author{
Olola Olayeye, Aduwo \\ Department of Accounting, Faculty of Management Sciences, Ekiti State University, Ado-Ekiti, Nigeria
}

\begin{abstract}
This study examinedthe effectiveness of budgeting and budgetary control on the performance of Ado-Ekiti Local Government in Nigeria.In this study, we adopted a descriptive research design with datagathered through questionnaire administered to some selected respondents. The non-parametric tool of chi square was employed to analysethe data. The hypotheses were tested and analyzed on a $5 \%$ level of significance and it was revealed that budgeting is a usefultool that guides local government to evaluate whether their goals and objectives are actualized. Considering the changing environment in which governments now operate and serve, it can be concluded that budget, which is a continuous management activity, should adaptto changes in the dynamic business environment. Keywords: Budgeting, Budgetary Control, Local Government, Ado-Ekiti, Performance
\end{abstract}

DOI: $10.7176 / \mathrm{RJFA} / 10-8-06$

Publication date: April $30^{\text {th }} 2019$

\subsection{Introduction}

The society wants are limitless but the resources to satisfy are extremely limited. Communities demand for public utilities to make them confortable in their living standards.Local government needs to statutorily provide basic needs such as good road,street lightening, drains,publichighways,provision and maintenance of public conveniences, provision and maintenance of primary, adult and vocational education and so on.It is therefore paramount forevery serious project undertaken by the local government to produce at that possible minimum cost so as to properly serve the people and ensure steady progress. In view of this, there is every need to do a realistic planning of the activities of the local government taking into consideration the limiting factors and the long term objectives of the local government.Budgeting has long been considered asa necessary tool in managing organization resources. Chartered Institute ofManagement Accountants explained budget as a qualitative statement prepared and approved prior to adefined period of time for the purpose of attaining a given objective. It may include income, expenditure andthe employment of capital. Chartered Institute of Management Accountants also stated that budgetary control isthe establishment of budgets relating theresponsibilities of executives to the requirements of apolicy and the continuous comparisons of actual withbudgeted results, either to secure by individual action theobjectives of that policy or to provide a basis for its revision.

Horngreen and Foster (2002) defined a budget as a quantitativeexpression of a plan of action and also assist coordinationand implementation. Therefore, planningis an important blue print of business growth and a clear road map fordevelopment that helps in deciding objectives, quantitatively and qualitatively. Planning involves setting a goal on thepremise of the objectives and keeping of the resources.Planning process requires that the managers of business or the government to act as if they are fortune tellers and attempt topredict the future course of action to be adopted. These predictions of the managers or the government will determinewhether or not the objectives of the organization will be met.Budgetsare plans that deal with future allocations and utilization of resources to different activities over a given period oftime. For any organization to make progress or achieveits goals it needs capital and to be able to make profit, itrequires planning of its resources, which can only beachieved through budgeting, budgeting then serves as atool for financial planning.Budgetary control is defined as a systemwhich uses budgets as a means of planning and controlling all aspects of producing and or selling commoditiesor services. This definition is true as we tend to prepare revenueand expenditure variance analysis so as to be able to deduceareas of divergences for which the government needsto watch to avoid embarrassment as any adverse variancewill translate into inability to meet the corporate objective which will eventually lead to disagreement withstakeholders.The factthat resources are scarce, coupled with high expectationthat rests on the government, budgets when rightlyapplied, would be an effective tool for planning and control, especially in a community such as Ado-Ekiti Local Government administration.

Budget is guideto making and coordinating short range plan; a devicefor communicating plan and objectives to various responsibility centers and a basic evaluation of performance. Budget is a parameterwhich measures the actual achievement of people, departments, ministries and firms, while budgetary controlensures that actual results are positively or negatively inaccordance with the overall financial and policy objectives of the organization.The decision as to how to distribute limited financial and non-financial resources, in an effective and efficient manner, is an important challenge in all organizations and Local Governments. In most large and complex organizations, this task would be nearly impossible without budgeting. Without effective budget analysis and feedback about budgetary problems, many Local Governments would become bankrupt and considered ineffective. Some of the 
problems arise from inadequate data to formulate and implement a proper budget; and non-existence of welldefined structure, which leads to overlapping of duties. These deficiencies can therefore be addressed through the use of budgeting technique and budgetary control. Therefore, the study intends to evaluates the effectiveness of budgeting and budgetary control on theperformance of Ado-Ekiti Local Government administration in Nigeria

\subsection{Conceptual Literature}

Budgets are statements of estimated resources set for execution of planned activities over a specified period of time. It is a blue print of the outcome of the organization's operation in a financial year and indicates the qualitative parameters of an organization's performance, while budgetary control is a process of finding out what is being done and involves the act of comparing the actual result with the budget to verify accomplishment or remedy the differences.Budget is a financial plan summarizing the financial experience of the past, the current plan and projection over a specified period of time in future. Short term budget is established for use for a short period of time, usually a yearwhich responsible officeruse for control purposes. This is commonly in use in manufacturing industries due to the complex and dynamic environment in which they operate.This is a long term plan called development plan normally use for a minimum 5 years. Government prepares 5 years Development plan which can be rolled over for every five year as manufacturing companies also prepare 5 years strategic plans, which is sometimes split into yearly budget rolled over from one year to the other.Fixed budget is a budget set prior to a control period and not subsequently changed in response to changes in any activity costs or revenues. It may serve as a benchmark in performance evaluation. Flexible budget is a budget designed to change in accordance with the level of activity attained. This budget recognizes the existence of fixed, variable and semi-variable costs and is designed to change in relation to the actual volume or output or level of activity in a period.Rolling budget is a system of budgeting that involves continuously updating budgets by reviewing the actual results for a specific period in the budget and determining a budget for the corresponding time period. Under this period, instead of preparing a budget annually, there would be budget every three or six month so that as the current period ends, the budget extended by an extra period.

\subsection{Organisational Performance}

This deals with the analysis of an organisation performance when the outcome iscompared to its goals and objectives. According to Upadhaya, Munir and Blount (2014), organizational outcomes can be judged from three specific areas, which are Financial performance (profits, return on assets, return on investment); Market performance (sales, market share,); and Shareholder's return (total shareholder return, economic value added). Similarly, government performance especially the local government performance may be assessed through the provision of basic social amenities and achievement of statutory responsibilities.

\subsection{Budgetary Control System}

Budgetary control is a system of controlling costs which includes the preparation of budget, coordinating the departments and establishing responsibilities, comparing actual achieved maximum profitability (Nweze, 2004). Nweze identified the objectives of budgetary control to include: to coordinate all the activities of business, to plan and control income and expenditure so that maximum profitability are achieved, to provide yardstick against which actual results can be compared, to acts as a guide for management decisions when unforeseeable conditions affect the budget and to ensure there is adequate labour force and it is fully utilized. Therefore organization of budgetary control include: budget departments, the introduction of adequate accounting records, general instructions of operating the system, the preparation of an organizational chart, the establishment of a budget committee, the preparation of a budget manual, budget periods and level of activity.

\subsection{Empirical Studies}

Mwaura (2010) employed descriptive research design to investigate the factors affecting participatory budget setting and budget commitment and financial performance of companies listed in Nairobi Stock Exchange. The outcome of Mwaura's study revealed that at return on capital and assets are influenced significantly by budgetary control in Nairobi Stock Exchange. Furthermore, the study revealed that budget commitment and financial performance in Nairobi Stock Exchange are positively connected. Karanja (2011) employed descriptive research design to examined effects of budgetary control systems in saving and credit cooperative in Nyeri country and a sample of 23 stratums was used for the study. The author concluded that finance officers mainly participated in budgetary control processes which assisted the saving and credit cooperative's to attain set financial goals. Nickson and Mears (2012) studied budgetary control and financial performance of government ministries in Boston Massachusetts for a period of ten years and sampled five ministries in the study. The regression model showed a positive relationship between the variables employed for the study.

Marcormick and Hardcastle (2013) examined the budgetary control and corporate financial performance in government entities in Europe for a period of 10years. The author employed a 40 government parastals for the 
regression model to analyse both the independent and dependent variables. The study found that budgetary control and performance of parastals are related positively. Abdirisaq and Ali (2013) examined the relationship between budgeting and performance in remittance companies in Mogadishu, Somalia. The researcher employed descriptive research design, standard deviation and correlation for the study and a sample of 103 was used. The author concluded that there is a moderate relationship between budgeting and remittance companies. Ekpenyon (2014) studied the application of budgets as a managerial tool for effective performance in university of Calabar, Nigeria. The study used survey design and obtained relevant information from 250 senior staff. The result of $t$-test statistics confirmed that the application of budgets in the University of Calabar as a managerial tool was effective. Kimani (2014) identified the effects of budgetary control on performance of non-governmental organisations in Kenya and a sample of 30 non-governmental organisations was used for the study. The researcher employed descriptive statistics and concluded that, there existed a slight positive relationship between budgetary control and financial performance of non-governmental organisations. Mburu (2015) conducted study on budgetary control and performance of constituency development funds in Machakos for the period of 2011-2014. The result of descriptive statistics employed to test the hypotheses concluded that participative budgeting with proper planning and monitoring and controls have a positive impact on performance of constituency development fund. Mutungi (2017) determined the effects between budgeting and budgetary control on financial performance of country governments in Kenya. The study investigated budgeting and budgetary control, managerial performance and country government. The researcher used quantitative descriptive research design to determine the relationship between budgeting and budgetary control and financial performance of developed governments and 47 country governments was used for the study. The study concluded that country government encounter challenges of budget implementation such as non -compliance with budgetary timeliness as required by Public Financial Management Act 2012. The study established a strong positive relationship between budgeting and budgetary control and financial performance.

\subsection{Conceptual Framework on Effectiveness of Budgeting and Budgetary Control in Ado-Ekiti Local Government}

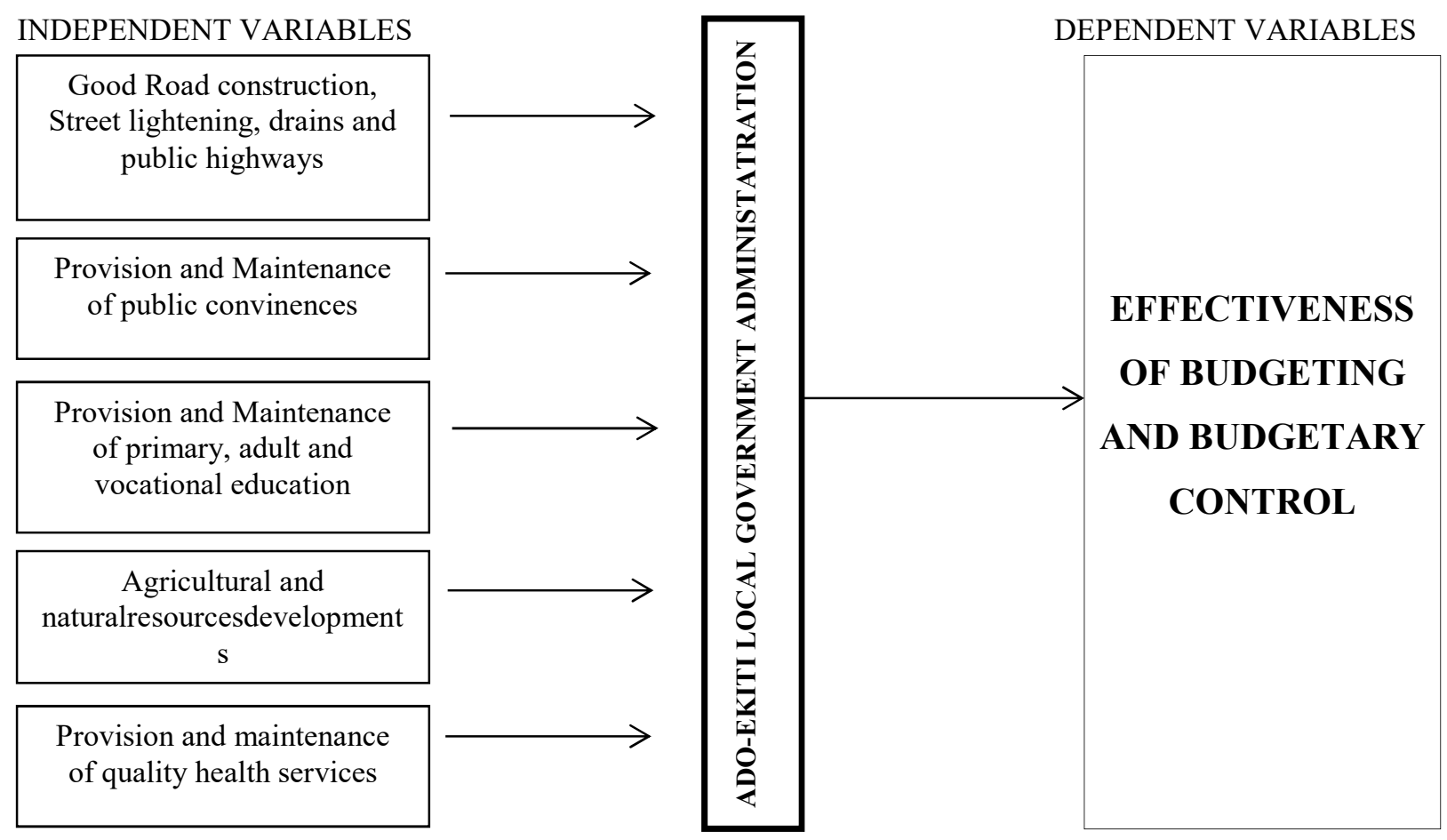

Figure 2.1: depicts the relationships between independent and dependent Variables used in the study. Sources: Author, 2018

\subsection{Theoretical Framework}

The model built for this study are underpinned by the allocation of resource theory, expenditure theory, economic theory and progressive theory of public expenditures as discussed below:

\subsubsection{Allocation of Resource Theory}

Allocation of Resource Theory was credited to Peteraf and Barney (2003). This theory dealt with the way 
Governments, corporate organisations and entrepreneursdistribute their financial resources through budgeting process to achieve their financial goals. Budgetary control mechanisms are used to allocate scarce economic resources in government institutions (Anantadjaya, 2008). With the aid of Invisible Hand Theory, researchers can understand how the allocations of resources are distributed through competition, supply and demand, entrepreneurs and government institutions (Peteraf, 2003). Government institutions, corporate organisations and entrepreneurs allocate their financial resources through budgetary process for the purpose to achieve their predetermined financial targets. Therefore, Allocation Resource Theory assists Ado Local Government in allocating its financial resources allocation at its disposal through budgetary control system.

\subsubsection{Expenditure Theory}

Expenditure theory was propounded by Rubin (1990). The theory provided explanations for the use of normative and descriptive theories. Budgeting process requires a normative theory to determine its critical policy on financial expenditures while normative theory expatiates while corporate expenditures are given priority and other expenditure are not given priority in the budgeting process (Posner and Blondal, 2012). Normative theory of budgeting helps to resolve conflicts in government decision making on budgeting process. Descriptive theory emphasized the participation in public financial activities on budget in other to meet financial objectives. This theory explained individual budget expenditures variation and to make us understand why expenditures changes from time to time (Ulrich, 2008). Therefore, government at Local levels use normative theory to choose projects to be executed depending on the acceptance of the project as stated in the budget.

\subsubsection{Economic Theory}

Economic theory was developed by Lewis (1952) in his efforts to explain that the concept of marginal utility could be used to determine the relative financial value of goods to explain the allocation of resources that the aggregate would improve financial performance of corporate entities. Economic theory explained the procedural methods for budgeting and put into consideration all scarce resources to attain financial performances of corporate entities. Due to the scarcity of the financial resources in response to demand, every expenditure would be worth its return and every financial cost would be equal to all its opportunity costs in order to achieve financial targets (Wicker, 2011). Incremental financial analysis is very important in each budget effectiveness.

\subsubsection{Progressive Theory of Public Expenditures}

Progressive theory of public expenditures was created by Walker (1951). Walker believed on a theory of expenditure based on cost-effective thoughts as preferable to dependence on theoretical claim to the argument of impartiality that was noneconomic and outside the government. Theory of expenditure allotment based on finances provided records to replace condemnatory influence and thus using marginal utility theory indifference point is discernable in the distribution of government budgets (Hildreth and Zorn, 2005). Progressive theory of public expenditure is important since Walker's work predated key budget writers, including Herbert Simons 'financial measurement research in Chicago (Walker, 2009). Walker suggests the norm for distribution of scarce financial resources and gives an approach for a positive budget process which leads to high corporate financial performance. This theorist further states that, public budgets must traverse the complex nature of executive legislative relationships in order to achieve the set financial goals.

\subsection{Methodology}

The method adopted for this study in collecting the data is the use of questionnaire. The data were generated from the responses of 150 out of 200 respondents randomly sampled in the course of this study. The research material was distributed to the five Local Governments under Ekiti South Senatorial District namely Ado Local Government Area, Efon Local Government Area, Ekiti West Local Government Area, Ijero Local Government Area, Irepodun/Ifelodun Local Government Area with more concentration on Ado Local Government Area. Five Local Government Chairmen's, five Directors of Finance, thirty eight Treasurers, nineteen Chief Accountants and eighty three Budget Officers were selected randomly to fill the questionnaire. A summary of the selection procedures are presented in table 1 and 2 below:

Table 3.1: Distribution of questionnaire in Ekiti South Senatorial District

\begin{tabular}{|l|l|l|}
\hline Local Government & No. Administered & No. Retrieved \\
\hline Ado Local Government & 60 & 46 \\
\hline Efon Local Government & 35 & 26 \\
\hline Ekiti West Local Government & 35 & 26 \\
\hline Ijero Local Government & 35 & 26 \\
\hline Irepodun/Ifelodun Local Government & 35 & 26 \\
\hline Total & $\mathbf{2 0 0}$ & $\mathbf{1 5 0}$ \\
\hline
\end{tabular}


Table 3.2: Status of Respondents

\begin{tabular}{|l|l|l|}
\hline Status & No. of Respondents & Percentages \\
\hline Chairman & 5 & 3.3 \\
\hline Director of Finance & 5 & 3.3 \\
\hline Treasurer & 38 & 25.3 \\
\hline Chief Accountant & 19 & 12.7 \\
\hline Budget Officer & 83 & 55.3 \\
\hline Total & $\mathbf{1 5 0}$ & $\mathbf{1 0 0}$ \\
\hline
\end{tabular}

The breakdown of table 2 above shows that of the 150 respondents, $5(3.3 \%)$ were Local Government Chairmen's, 5 (3.3\%) were Directors of Finance, 38 (25.3\%) were Treasurers, 19 (12.7\%) were Chief Accountants and $83(55.3 \%)$ were Budget Officers. Structured questionnaire was formulated to solicit respondent's perception on the effectiveness of Budgeting and Budgetary Control on the performance of Ado Local Government in Ekiti State. The questionnaire consists of two sections. Section A elicits demographic information like gender, working experience, educational qualification and status, while Section B contained structured items relating to the research questions that necessitated this research.

Table 3.3: Response to statement 1 to 5

\begin{tabular}{|l|l|l|l|l|l|l|}
\hline S/N & \multicolumn{1}{|c|}{ ITEM } & SA & A & D & SD & TOTAL \\
\hline 1 & $\begin{array}{l}\text { Ado Local Government budget achieve the construction of good } \\
\text { roads, street lightening, drains and public highways }\end{array}$ & 71 & 46 & 25 & 8 & 150 \\
\hline 2 & Budget helps to provide and maintain public conveniences & 50 & 71 & 15 & 14 & 150 \\
\hline 3 & $\begin{array}{l}\text { Budget assist to provide and maintain primary, adult and vocational } \\
\text { education }\end{array}$ & 73 & 35 & 32 & 10 & 150 \\
\hline 4 & $\begin{array}{l}\text { Ado Local Government Budgets achieve Agricultural and natural } \\
\text { resources development }\end{array}$ & 54 & 61 & 22 & 13 & 150 \\
\hline 5 & $\begin{array}{l}\text { Ado Local Government Budgets provide and maintain quality health } \\
\text { services }\end{array}$ & 52 & 62 & 21 & 15 & 150 \\
\hline Average & $\mathbf{6 0}$ & $\mathbf{5 5}$ & $\mathbf{2 3}$ & $\mathbf{1 2}$ & $\mathbf{1 5 0}$ \\
\hline
\end{tabular}

From the response frequencies above, a total of 115 (76.67\%) respondents accepted the statement that budget has helped to achieve the construction of good roads, street lightening, drains and public highways as well as help to provide and maintain public conveniences, primary, adult and vocational education, quality health services and budget has also helped to achieve agricultural and natural resources development while $35(23.33 \%)$ of the respondents objected to these statements.

\section{Table 3.4: Response to statement 6 to 10}

\begin{tabular}{|l|l|l|l|l|l|l|}
\hline S/N & \multicolumn{1}{|c|}{ ITEM } & SA & A & D & SD & TOTAL \\
\hline 6 & $\begin{array}{l}\text { Budgetary control aid to achieve the construction and maintenance of } \\
\text { good roads, street lighting, drains and public highways }\end{array}$ & 75 & 62 & 11 & 2 & 150 \\
\hline 7 & $\begin{array}{l}\text { Budgetary control help to achieve the provision of public } \\
\text { conveniences }\end{array}$ & 59 & 56 & 12 & 23 & 150 \\
\hline 8 & $\begin{array}{l}\text { Budgetary control assist in provision and maintenance of primary, } \\
\text { adult and vocational education }\end{array}$ & 66 & 61 & 16 & 7 & 150 \\
\hline 9 & $\begin{array}{l}\text { Budgetary control helps to achieve the development of Agriculture } \\
\text { and natural resources development }\end{array}$ & 67 & 58 & 19 & 6 & 150 \\
\hline 10 & $\begin{array}{l}\text { Budgetary control assist in provision and maintenance of quality } \\
\text { health services }\end{array}$ & 68 & 48 & 22 & 12 & 150 \\
\hline Average & $\mathbf{6 7}$ & $\mathbf{5 7}$ & $\mathbf{1 6}$ & $\mathbf{1 0}$ & $\mathbf{1 5 0}$ \\
\hline
\end{tabular}

From the response frequencies above, a total of $124(82.67 \%)$ respondents accepted the statement that budgetary control has helped to achieve the construction of good roads, street lightening, drains and public highways as well as help to provide and maintain public conveniences, primary, adult and vocational education, quality health services and budget has also helped to achieve agricultural and natural resources development while $26(17.33 \%)$ of the respondents objected to these statements.

\subsection{Results}

Table 4.1: Budgeting does not help to achieve statutory responsibility of Local Governments in Ado-Ekiti Local Government in Ekiti State, Nigeria

\begin{tabular}{|l|l|l|l|l|l|}
\hline Subject & No. & $\%$ & T - calculated & Table value & Decision \\
\cline { 1 - 3 } Agreed & 115 & 76.67 & & & \\
\cline { 1 - 5 } Disagreed & 35 & 23.33 & 1.83 & 0.27 & Reject \\
\hline
\end{tabular}

Level of significance -0.5 
Since t-calculated is greater than the table value (i.e. $1.83>0.27$ ), then the null hypothesis is rejected, while the alternative hypothesis is accepted and we concludethat Budgeting does help to achieve statutory responsibility of Local Governments in Ado - Ekiti Local Government in Ekiti State, Nigeria.

Table 4.2: Effective Budgetary Control does not help to achieve and improve performance in Ado-Ekiti Local Government in Ekiti State, Nigeria

\begin{tabular}{|l|l|l|l|l|l|}
\hline Subject & No. & $\%$ & T - calculated & Table value & Decision \\
\cline { 1 - 3 } Agreed & 124 & 82.67 & \multirow{2}{*}{2.60} & & \\
\cline { 1 - 5 } Disagreed & 26 & 17.33 & 0.31 & Reject \\
\hline
\end{tabular}

Level of significance -0.5

Since t-calculated is greater than the table value (i.e. $2.60>0.31$ ), then the null hypothesis is rejected, while the alternative hypothesis is accepted and we concludethat effective Budgetary Control does help to achieve and improve performance in Ado - Ekiti Local Government in Ekiti State, Nigeria.

\subsection{Discussion of Findings}

Finding of hypotheses tested reveals the followings:

The result of hypothesis one revealed that budgeting and budgetary control has helped Ado-Ekiti Local Government to achieve statutory responsibilities in terms of construction of good roads, drains and public conveniences, provision and maintenance of public conveniences, provision and maintenance of quality health services;Hypothesis two revealed that Ado Local Government budgetary control achieved satisfactory performance.

\subsection{Conclusion and Recommendations}

The relevant research questions raised above have been examined in the light of mode of operation of Ado-Ekiti Local government. The study concluded that Ado-Ekiti Local Government administration achieved budgeting provisions in the satisfaction of public utilities for the citizens in Ado-Ekiti communities, Nigeria.

The study recommended that the Local Government should adopt a standard budgetary system for adequate planning with strict adherence to its implementation. The study recommended that Local Government Legislators should pass appropriation bill regularly to improve Local Government performance and that budget plans should be statutorily executed to avoid financial performance challenges and to achieve quick public service delivery. The study recommends that further research should be conducted to ascertain financial performance of Local Government using another Local Governments and different variables for the study.

\section{References}

Abdirisaq, M. and Ali, A. (2013).Relationship between Budgeting and Performance of Remittance Companies in Somalia.Faculty of Business and Accountancy, Simad University, Mogadishu, Somalia.

Anantadjaya, S.P. (2008). Comparative Literature, study on the Resource-Based Theory of the Firm and knowledge-Based Theory of the Firm. OECD Journal on Budgeting, 3(1), 39-50.

Chartered Institute of Management Accountants (2000). Management Accounting Official Terminologies. CIMA

Ekpenyong, E.E. (2014). Zero Based Budgeting as a Management Tool for Effective University Budget Implementation.Department of Educational Administration and Planning, University of Calabar, Nigeria.

Hongren, C.T. and Foster, G. (2002).Cost Accounting: A Managerial Emphasis. New Jersey: Prentice Hall Inc.

Karanja, C.G. (2011). The Effect of Budgetary Control Process in NyeriCountry Saccos, Unpublished MBA, University of Nairobi

Kiman, R.N. (2014). The effects of budgetary Control on Effectiveness of Non-Governmental Organisations in Kenya.Unpublished M. Sc. Thesis Submitted to School of Business, University of Nairobi.

Koontz, Donnel, H and Cyril (1979).Principle of Management: An Analysis of Managerial Functions. New York: McGraw Halls Book Co.

Marcormick, G. \&Hardcastle, N. (2011).Budgetary Control and Organisational Performance.Journal of Finance and Accounting, 2(1), 1-8.

Mburu, N. (2015). The Relationship between Budgetary Control and Performance of Constituency Development Fund in Machakos Country.Unpublished MBA, Submitted to School of Business Administration, University of Nairobi.

Mutungi, Z.W. (2017). Effects of Budgeting and Budgetary Control on Performance of Devolved Government in Kenya.Unpublished M.Sc. Thesis Submitted to School of Business, University of Nairobi.

Mwaura, N. (2010). The Relationship between Budgetary Participation and Financial Performance of Companies Quoted at the Nairobi Stock Exchange.Unpublished MBA, University of Nairobi.

Nickson, J. \& Meats, S. (2012). Budgetary Control and Performance. Journal of Finance, 7(3), 78-98.

Nweze, A.U. (2004). Profit Planning(2 ${ }^{\text {nd }}$ Ed.).Enugu: M'cal Communications International.

Peteraf, M.and Barney, J. (2003). Unraveling the Resources-Based Tangle, Managerial and Decision Economics. 
International Business Journal, 24(1), 309-323.

Posner, P. and Blondal, J. (2012). Democracies and Deficits: Prospects for Fiscal Responsibility in Democratic Nations. Governance Journal, 25(1), 11-34.

Ulrich, B. (2008). World at Risk: The New Task of Critical Theory. Development and Society, 37(1), 1-21.

Upadhaya, B., Munir, R. and Blount, Y. (2014), Association between Performance Measurement Systems and Organizational Effectiveness.International Journal of Operations \& Production Management, 34(7), 23-40. Walker, J. (2009). Budgetary Planning and Control Accounting in a Nutshell.293-318. 